\title{
Ecophysiological aspects of in vitro biotechnological studies using somatic embryogenesis of callus tissue toward protecting forest ecosystems
}

\author{
Katarzyna Nawrot-Chorabik ${ }^{1} \cdot$ Marcin Pietrzykowski $^{2}$
}

Received: 14 November 2017/ Accepted: 19 March 2018/Published online: 11 December 2018

(c) The Author(s) 2018

\begin{abstract}
This review on current biotechnological methods in forestry for in vitro tissue cultures to define the effect of stress conditions on trees, concentrates on somatic embryogenesis. Callus tissue, the key product of somatic embryogenesis, grows over a tree wound under ex vitro conditions. Callus tissue can be used in research in areas such as pathogenic susceptibility at the embryonic level, effect of heavy metals, influence of low temperatures (cryopreservation), production of secondary metabolites and transformation of plants. Callus of arborescent plants can be induced in vitro by fungal elicitors to produce secondary metabolites for pharmaceutical and cosmetic industries and are strongly repellant to herbivores and can thus act to protect forests. Analyses of dual cultures demonstrated that callus tissue exposed to a pathogenic fungus responds by synthesizing low-molecular-mass proteins belonging to an immune protein class. Cryopreservation of embryonic callus tissue also has broad applications, e.g., for valuable plant genotypes in gene banks. Without strategies to protect forests against stress
\end{abstract}

Project Funding: The work was supported by DS 3414 theme from the Polish Ministry of Education and Science.

The online version is available at http://www.springerlink.com

Corresponding editor: Hu Yanbo.

Katarzyna Nawrot-Chorabik

rlnawrot@cyf-kr.edu.pl

1 Department of Forest Pathology, Mycology and Tree Physiology, Institute of Forest Ecosystem Protection, 31-425 Krakow, Poland

2 Department of Forest Ecology and Reclamation, University of Agriculture in Krakow, 29-Listopada Ave 46, 31-425 Krakow, Poland factors, forest ecosystems will degrade to the detriment of all life, including humans. In vitro biotechnological research using callus tissue contributes to progress in forestry and the disciplines of ecology, physiology, phytopathology, culture and selection of plants.

Keywords Callus · Environmental stress · Micropropagation · Tissue cultures · Trees

\section{Introduction}

Recently, beside prevention and restoration programs in forestry to suppress or restrain tree diseases, new methods of forest protection are being implemented, especially in vitro biotechnological methods which have been broadly applied to agriculture (Herdt 2006), horticulture (McCown 2003) and commercial culture of tropical grasses (palms) (Abul-Soad and Mahdi 2010). Since the second half of the 1980s, new biotechnological research directions have been applied worldwide in forestry and led to numerous specialized methods, including in vitro tissue culture via somatic embryogenesis, designed especially for gymnosperm species (Litz et al. 1995; Giri et al. 2004), and organogenesis for gymnosperms and angiosperms (Rangaswamy 1986). Somatic embryogenesis results in a potentially high efficacy of micropropagation by yielding valuable, highly selected plant reproductive material (Rodríguez et al. 2007), enabling research on pathogenicity at the embryonic stage of plant development (using callus tissue) (Hendry et al. 1993; Nawrot-Chorabik 2014; Nawrot-Chorabik et al. 2011, 2016), production of secondary metabolites (Mulabagal and Tsay 2004), transformation of plants (Walters et al. 2005), and cryopreservation of plant material (Misson et al. 2006; Hargreaves and 
Menzies 2007; Nawrot-Chorabik and Sitko 2014). These broad applications explain the increasing interest in somatic embryogenesis and its indirect product, callus tissue.

Callus, a tissue covering wounds in living plants under natural conditions, can be obtained in vitro from arborescent plants isolates, so called explants. Therefore, laboratory obtained callus tissue is an intermediate effect of embryogenesis of forest trees. Cultured callus tissue is a mass of unorganized, proliferating, well-hydrated cells of different colors depending on the type and regenerative potential (embryogenic or non-embryogenic) and plant species. The structure of callus can be loose or tight. Callus cells initiated by somatic embryogenesis are totipotent, with an unlimited ability to proliferate and differentiate to regenerate the entire organism.

Research to refine and develop applications for somatic embryogenesis of economically important trees species are progressing for Abies (Salaj and Salaj 2003; NawrotChorabik 2008, 2009), Picea (Mihaljević and Jelaska 2005; Klimaszewska et al. 2010), Pinus (Klimaszewska et al. 2001; Lelu-Walter et al. 2008), Taxus (Nhut et al. 2007), Acer (Ďurkovič and Mišalová 2008), Castanea (Corredoira et al. 2003), Quercus (Toribo et al. 2005), Salix (Naujoks 2007) and Ulmus (Malá et al. 2007; Ďurkovič and Mišalová 2008). Micropropagation of most of these species has yielded callus to select and generate seedlings with desired features. Beside micropropagation for commercial purposes, e.g., green twig or Christmas tree production in Caucasian fir plantations (Misson et al. 2006), protocols have been established to obtain callus tissue from selected trees species for use as a base material for pharmaceutical, medical and cosmetic industries, such as the extraction of taxol from Taxus sp. (Cusidó et al. 1999; Das et al. 2008), juglone, one of the most antiseptic compounds in nature, from Juglans regia (Bolonkowska et al. 2011), and saponin, the source of substrates to produce steroids and hormones, from Aesculus hippocastanum (Sparg et al. 2004).

Callus tissue in sustained cultures changes the genetic stability, which is not a significant obstacle for biochemical research but is not economical for commercial micropropagation. Therefore, for the regeneration of plants from in vitro cultures, long-term observation of growth and development variables of a vast number of somatic seedlings, representing many genotypes without somaclonal variations, is indispensable (Heinze and Schmidt 1995; Nawrot-Chorabik 2009). On the other hand, for synthesizing secondary metabolites or doing other biotechnological experiments, the composition of the culture media must be optimized for the selected species, and the tissue has to be subcultured to proliferate quickly. For ex vitro and in vitro cultures, in vitro conditions (e.g., external environment conditions, correct disinfection of plant material) must generate desirable plants of valuable species commercial production in laboratories worldwide.

Research on tissue cultures is conducted in numerous countries, including the United States and Canada, where in 2001 Park's team involved in silviculture and forest tree selection using somatic seedlings of white spruce (Picea glauca), the most common tree species in Canada. The production of somatic seedlings is economically profitable and has been successfully applied in many countries including Great Britain, Israel, Italy, China and France, where seedlings of Pinus pinaster were used to establish new forests (Cyr and Klimaszewska 2002). In Poland, research on micropropagation of trees using somatic embryogenesis is conducted primarily at the Forest Research Institute in Warsaw on European larch (Larix decidua) (Szczygieł 2005) and on genetic variation of wild cherry (Prunus avium) and wild service tree (Sorbus torminalis), toward generating valuable lumber (Szczygieł and Wojda 2008). Moreover, research on somatic embryogenesis of selected conifers and deciduous trees species (e.g., Picea or Fagus) (Hazubska-Przybył et al. 2013) and cryopreservation of callus tissue and somatic embryos (Hazubska-Przybył et al. 2010, 2012, 2013) are conducted at the Institute of Dendrology of Polish Academy of Sciences in Kórnik. In the Department of Forest Pathology, Mycology and Tree Physiology of the University of Agriculture in Krakow, comprehensive biotechnological research includes somatic embryogenesis of Abies alba (Nawrot-Chorabik 2008), A. grandis (Nawrot-Chorabik 2007), A. nordmanniana (Nawrot-Chorabik 2016), and Pinus sylvestris, P. nigra (Nawrot-Chorabik 2015a) and Picea abies (Nawrot-Chorabik et al. 2011) and studies on cryopreservation of callus tissue and somatic embryos (Nawrot-Chorabik and Sitko 2014) and stress factors affecting forest trees (Nawrot-Chorabik 2014, 2017; Nawrot-Chorabik et al. 2016).

Here we review current knowledge and biotechnological research on ecophysiological aspects of tissue cultures, with an emphasis on somatic embryogenesis using tree callus tissue and potential applications for protecting forest ecosystems. Research on somatic embryogenesis to generate callus tissue will be discussed, disinfection of plant material and composition of culture media will be described and the role of callus tissue in studying the effect of environmental stress factors on trees will be considered.

We also discuss relevant directions for future research on in vitro cultures, emphasizing the contribution of callus tissue to the study of tree responses to stress. Somatic embryogenesis is an indispensible alternative to vegetatively propagate trees (Szczygieł 2005), especially to preserve endangered trees species, that are important economically and ecologically, and to increase forest productivity. 


\section{Plant material and general sterilization guidelines}

Base plant materials derived from forest trees are primeval explants, and callus cultures are induced from these explants (other plant cuttings are secondary explants) placed on solid or liquid media. The preferred types of primeval explants for somatic embryogenesis are mature zygotic embryos isolated from ripe seeds of trees, megagametophytes (i.e., immature seeds from unripe cones), buds, conifer or hardwoods leaves and cell protoplasts. Primeval explants are selected based on the age of tissues and organs of the parent plant (young parts have higher developmental potential) and physiological maturity.

Explants used to start a new culture have to be appropriately surface-sterilized using a procedure and chemical agent that are optimized for the tree species and the type of primeval explant. Optimizing the sterilization procedure for trees such as species of Fagaceae can be difficult and complicated (Kraj et al. 1999) due to their sizeable seeds and microbial colonization including numerous endophytic bacteria and fungi (Kowalski and Kehr 1992; NawrotChorabik and Jankowiak 1999). The entire process can require up to 2 days. For somatic embryogenesis of species of Abies, Pinus and Picea (Nawrot-Chorabik 2008, 2016; Nawrot-Chorabik et al. 2011, 2015a, b), seeds are precooled in a solution of antioxidants $(5.0 \% \mathrm{v} / \mathrm{v}$ ascorbic acid or polyvinylpyrrolidone in sterile water), for $24 \mathrm{~h}$ in $4{ }^{\circ} \mathrm{C}$. This application of antioxidants is an innovative step, facilitating isolation of somatic embryos and inhibiting secretion of phenolic glycosides in seeds that interfere with callogenesis (Nawrot-Chorabik 2016). Regular shaking while rinsing and the addition of substances to release surface tension (e.g., Tween 80) to facilitate penetration into the sterilized material surface are advised. In specific cases (e.g., fir), a fungicide(s) or antibiotic(s) is required, but may decrease the frequency of further callus initiation. Nawrot-Chorabik (2016) developed a protocol that guarantees a high percentage of sterilized explants of Abies nordmannia capable of morphogenesis. Sterile, horizontally oriented explants are placed gently on the surface of solid initiation medium to avoid too strong immersion.

\section{Culture media composition}

The culture medium for each stage of in vitro somatic embryogenesis must be modified and optimized for the intended result, mainly by altering the types and concentrations of phytohormones, carbohydrates and other components. Media for arborescent plants are rich in macroand microelements, vitamins, growth regulatory hormones and, in some cases, the source of amino acids (enzymatic casein hydrolysate), as recommended for species of Abies (Nawrot-Chorabik 2008, 2016). The pH of media for woody species ranges from 5.7 to 5.8. For gymnosperm trees under laboratory conditions, solid medium is preferred, in contrast to liquid medium used in industrial bioreactors. Macroelements are provided as inorganic salts at $3000 \mathrm{mg} \mathrm{dm}{ }^{-3}$ to regulate permeability of cell membranes and are involved in building chlorophyll molecule. Microelements are also provided as inorganic salts but between 0.03 and $100 \mathrm{mg} \mathrm{dm}^{-3}$. Vitamins (e.g., pyridoxine, thiamine, biotin and nicotinic acid, folic acid and myoinositol) influence physiological condition of cells and are indispensable for callus tissue proliferation. Disaccharides (sucrose and maltose) serve as the carbon source and to stabilize the osmotic balance by regulating uptake of compounds determining cell development. Phytagel or Agargel is added to solidify media. Auxins such as 2,4-Ddichlorophenoxyacetic acid (2,4-D), indole-3-butrric acid (IBA), 4-amino-3,5,6-trichloropicolinic acid (picloram) and cytokinins such as benzylaminopurine (BA), kinetin (KIN), thidiazuron (TDZ) stimulate callus growth by regulating gene expression. Auxins are responsible for differentiation of primeval explants cells, which leads to activation of embryogenic potential. Cytokinins stimulate biosynthesis of nucleic acids and structural and enzymatic proteins, inhibit ribonucleases and proteases activity, and actuate cell division (Nawrot-Chorabik 2015b). Growth regulatory phytohormones are crucial for the differentiation of embryos generated in subsequent phases (globular, heart-, torpedo- and cotyledon-shaped; Fig. 1a-c) (NawrotChorabik 2016). Subsequent rooting, then acclimatization of plantlets and finally, the generation of autonomic seedlings represent sizeable problems during micropropagation (Nawrot-Chorabik 2012). The difficulty of inducing microcuttings to root is a primary reason that micropropagation techniques are not widely used for many important tree species (Malá et al. 2005).

\section{Phenotypic differentiation of callus tissue to study stress factors in trees}

Callus tissue, which is induced at the initial stage of in vitro somatic embryogenesis of forest trees (callus initiation) and cultured during the second stage of culture (proliferation), is characterized by heterogeneity. Immediately after initiation of the explant, the tissue demonstrates diversity in its morphological features. Up to the third week of in vitro culture, incubation zones of the callus can be characterized by such properties as color (white, green, bright cream; Fig. 2a, b), consistency (dense and rare fragments; Fig. 2c), and structure (viscous, sticky, firm, 

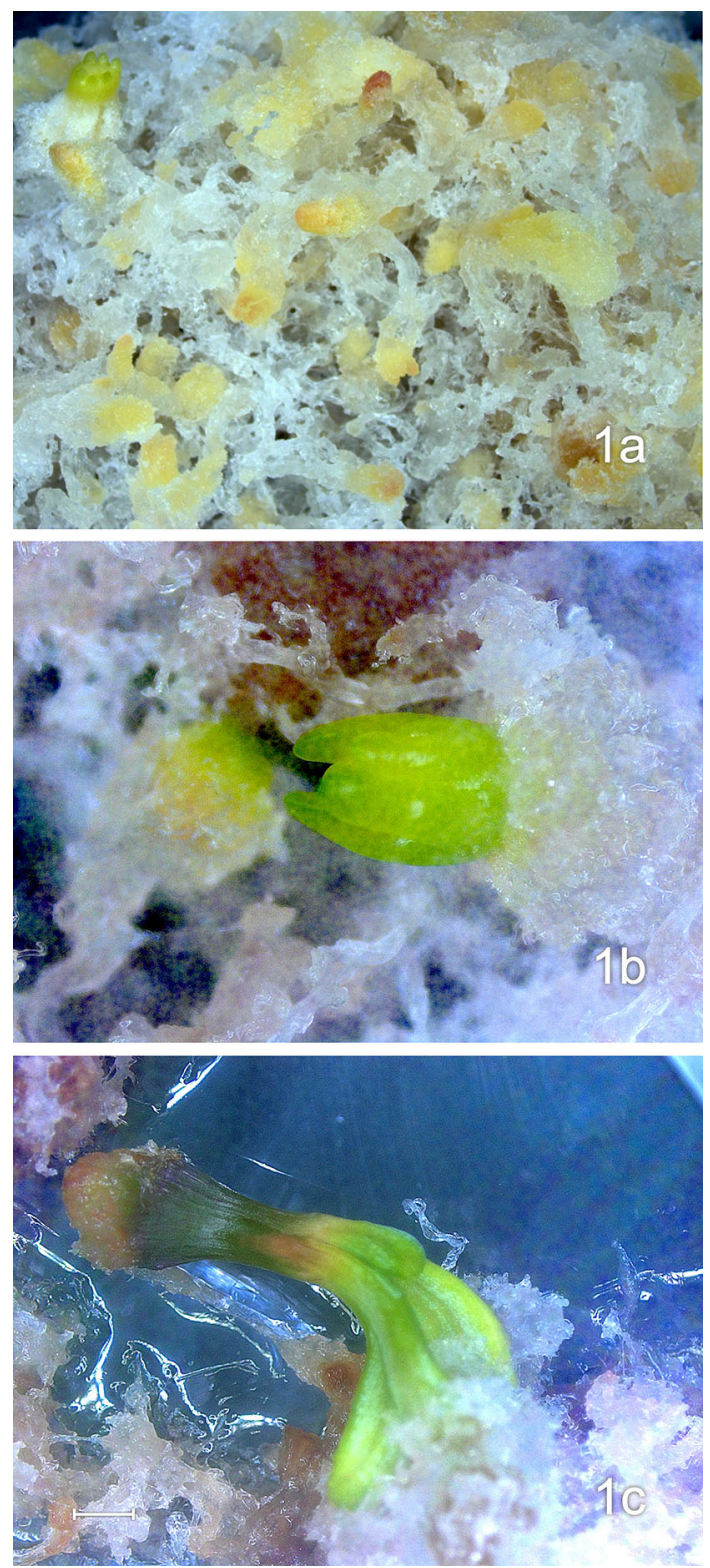

Fig. 1 Stages of somatic embryo development generated by embryogenic callus tissue of Caucasian fir (Abies nordmanniana): globular $(\mathbf{a})$, torpedo-shaped $(\mathbf{b})$, cotyledon-shaped $(\mathbf{c})($ scale bar $=10 \mathrm{~mm})$

spongy; Fig. 2b, d) (Nawrot-Chorabik 2016). Not earlier than after first passage (transfer of explants with initiated callus to a new type of medium, e.g., solid), that is, after 3-4 weeks, callus tissue becomes monolithic. Embryogenic callus is transparent to a color between white and straw-cream, its consistency is soft and hydrated, and the structure is glutinous, loose and homogeneous (Fig. 3a, b) (Nawrot-Chorabik 2008, 2015a). Non-embryogenic callus is transparent or yellow to green, firm and dry, dense and compact, with a rough to nodular surface (Fig. 3c) (Nawrot-Chorabik 2015a). Depending on the type, the callus may be used for different purposes, e.g., trace metal studies (embryogenic callus), pathogenicity assessment (embryogenic and non-embryogenic callus), resistance to low temperature evaluation (embryogenic and non-embryogenic callus), tree micropropagation (embryogenic callus) and secondary metabolites studies (non-embryogenic callus).

\section{Tissue cultures in biotechnological applications for forest trees}

A variety of techniques and analyses are used to improve plant quality, increase resistance to stress factors and obtain secondary compounds to benefit humans. Somatic embryogenesis and organogenesis were first applied to forestry, supporting pioneer research to develop micropropagation techniques for economically important forest tree species. Techniques were then developed for horticulture species, which are less burdensome (e.g., in harvesting material). In the 1950s, somatic embryos of carrot (Daucus carota) were initiated (Steward 1958), and in 1965, the first embryos of a deciduous tree species (sandal tree, Santalum album) were obtained (Rao 1965). Callus tissue was then induced in vitro for pioneer conifers in 1985 (Chalupa 1985; Hakman et al. 1985). Ten years later, callus tissue from suspension cultures was used to study secondary metabolites (Dörnenburg and Knorr 1995).

Callus as a tissue generated indirectly during embryogenesis was used primarily for studies of secondary metabolites. Callus tissue is cultured on solid or liquid media (suspension cultures). Among the metabolites synthesized pharmaceutical drugs, natural pigments, fragrances and even pesticides (Bourgaud et al. 2001). Since the 1990s, the experimental importance of tissue cultures has increased, especially in terms of research on elucidating the biosynthetic pathway of paclitaxel (Taxol) in Taxus species (Seki et al. 1995). A high concentration of Taxol is produced by Taxus chinensis callus cultured in vitro on MS medium (Murashige and Skoog 1962). Taxol is then extracted and analyzed using HPLC with a UV detector (wavelength $227 \mathrm{~nm}$ ). Samples cultured on medium with fungal elicitors demonstrated 2.6 times higher efficacy of Taxol production than in the control without the elicitors (Wang et al. 2001). Elicitors, both biotic (fungi, microorganisms) and abiotic (UV, freezing, chemical agents such as herbicides) influence metabolite production. A fungal preparation derived from Aspergillus niger and Rhizopus oryzae added to the culture medium for the flowering plant Plumbago rosea induced 3 times greater synthesis and secretion of plumbagin (analgesic glycoside) compared with the control (Komaraiah et al. 2002). Species of Betula, Salix, and Populus synthesize monoterpenes and isoprenoids (birch) and phenolic glycosides (Salicaceae 
Fig. 2 Phenotypic

differentiation of Abies

nordmanniana callus tissue:

heterogeneity in color (a green;

b cream), consistency (c) and

structure (d) (scale

bar $=10 \mathrm{~mm}$ )
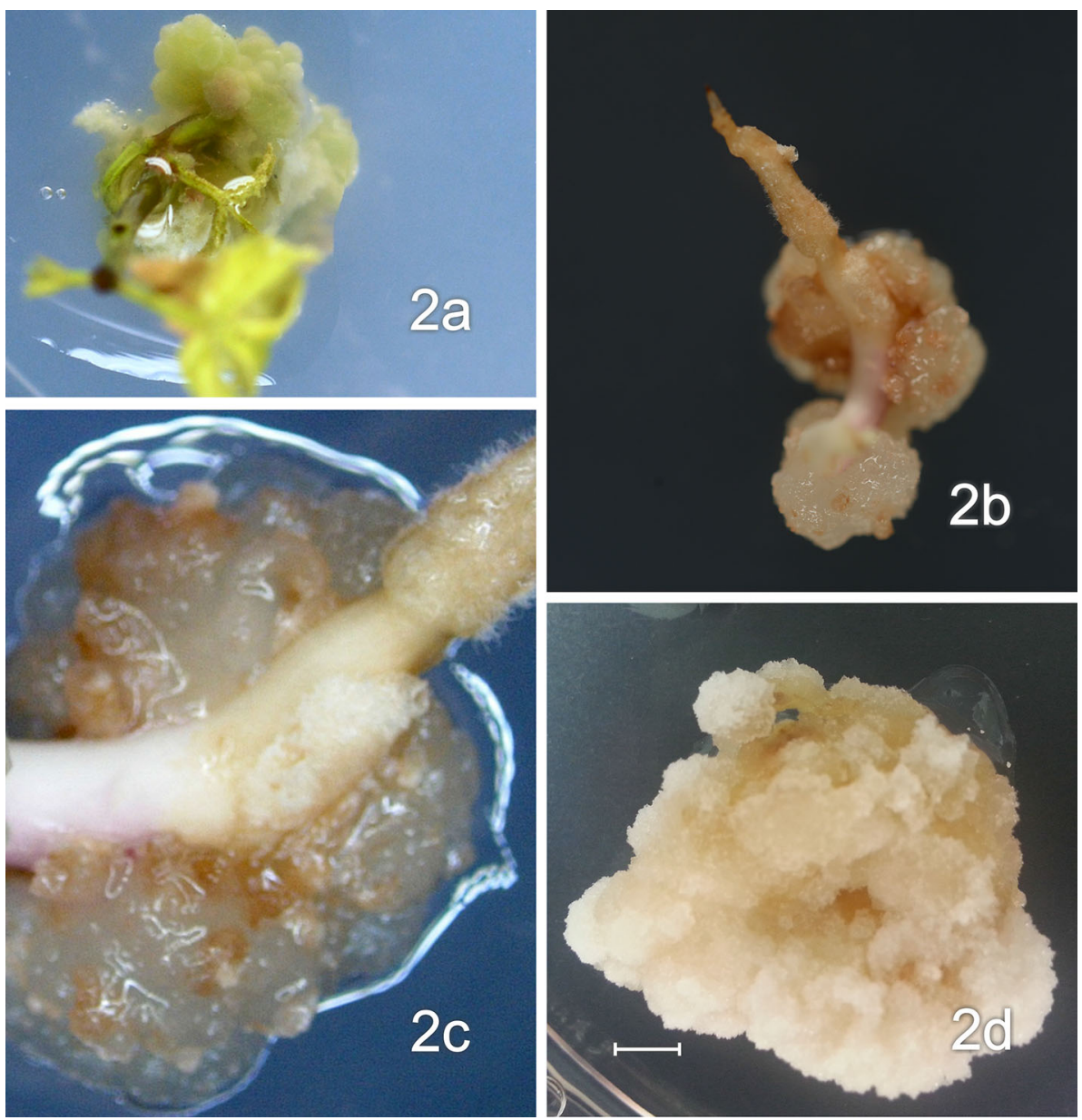

family), important compounds in pharmaceutical and cosmetic industries, and have strong herbivore-repelling properties, in culture media (Palo 1984).

Valuable secondary metabolites can also be synthesized efficiently by endophytic fungi in cultured plant tissue (that is, in vitro dual cultures of callus and fungus) cultures and were studied by Schulz et al. (2002) in terms of co-activity of biologically active metabolites. Endophytic fungi produce isozymes indispensable for host plant colonization and grow well in the apoplast of the plant. Endophytes colonizing roots of larch remain in mutualistic relationship with the tree, providing protection from herbivorous insects. If the balance is disturbed by one of the organisms in this relationship, however, the symptoms of the disease disclose (Schulz et al. 2002). Secondary metabolite production needs to be further studied and developed toward controlling synthesis in fungal and plant cells and reducing costs of extraction and purification.

The importance of in vitro dual cultures increases in terms of the secondary metabolites and fungi as elicitors of callus tissue. Non-embryogenic callus tissue is usually indispensable for dual cultures, in which fungi with different trophic properties are also used (Nawrot-Chorabik
2013, 2014). Such studies can be used to obtain cultures of non-embryogenic callus tissue via somatic embryogenesis, determine the virulence of a fungus based on their growth rate and damage to plant (callus) tissue cells, and analyze proteins (SDS-PAGE) synthesized under stress conditions. Nawrot-Chorabik et al. (2016) compared fungal species that have different trophic properties and selected those that activated specific defence mechanisms in the callus. Non-embryogenic callus of Pinus sylvestris exposed to stress factors such as a highly virulent fungus produced low-molecular-mass proteins, probably belonging to the plant immune PR (pathogenesis related) protein class (sequencing is required to confirm the class). Various genotypes of callus tissue can be initiated and proliferated by somatic embryogenesis or clones of selected lines can be grown (Nawrot-Chorabik 2013) in dual cultures with a particular pathogen to select and micropropagate plant genotypes that are resistant to the pathogen (Fig. 4). Such tests can also be helpful for elucidating metabolic pathways for secondary metabolite production in plant tissue and endophytic fungi.

Embryogenic and non-embryogenic callus tissue can also be used to study the effects of heavy metals on forest 

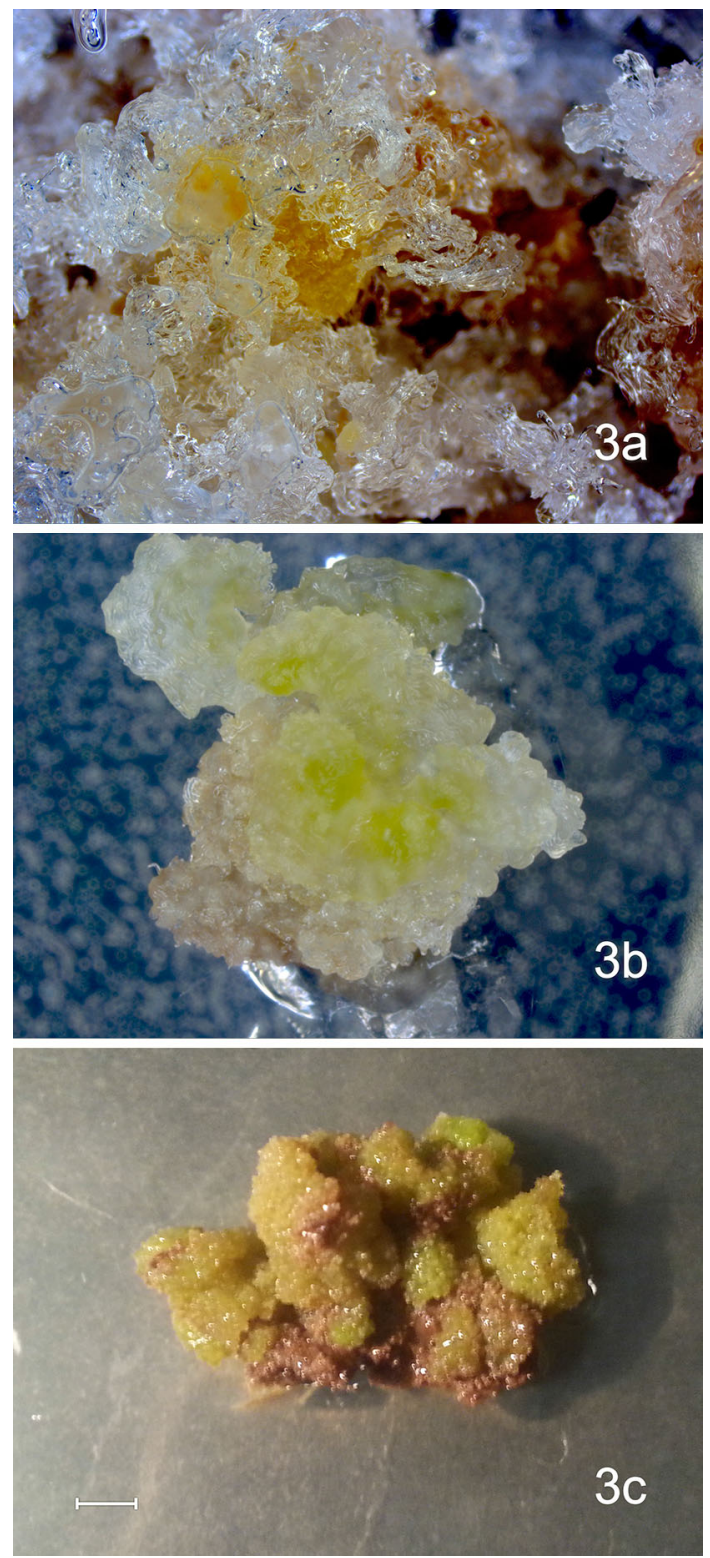

Fig. 3 Embryogenic callus tissue of Abies alba (a), Pinus sylvestris (b), and non-embryogenic callus tissue of Pinus sylvestris (c) (scale bar $=10 \mathrm{~mm}$ )

trees. In studies of three genotypes of Abies nordmanniana callus tissue treated with copper, lead and cadmium, metal accumulation levels were measured. The analyses confirmed high lead accumulation $\left(\mathrm{Pb}^{2+}>0.30 \mathrm{mM}\right)$, which leads to environment degradation and can be harmful for living organisms including plants and humans (NawrotChorabik 2017). These results correspond with those of Agrawal and Sharma (2006) that lead and cadmium cause more severe disruptions of cell metabolism compared to other metals.

Embryogenic callus grown via somatic embryogenesis can also be cryopreserved using liquid nitrogen

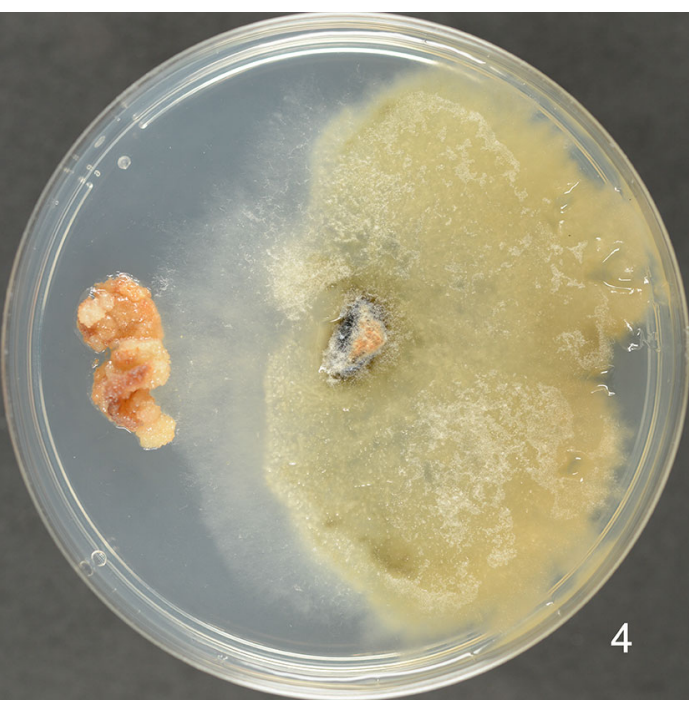

Fig. 4 In vitro dual culture of Fraxinus excelsior callus tissue and the fungus Valsa cypri

$\left(-196{ }^{\circ} \mathrm{C}\right)$. Cryopreservation is considered the best method for long storage of in vitro cultures including callus, somatic embryos, pollen, buds and tree seeds. During storage at such low temperature, cell division and metabolism are restrained. The method takes little space and is relatively cheap. Because genetic stocks in gene banks has been enriched with new, valuable genotypes of endangered, economically or ecologically important trees species through biotechnology, successful cryopreservation has become indispensable to increase tissue resistance to dehydration and redehydration after defrosting. Cells must be in a non-crystalline state of vitrification to survive dehydration and freezing. During dehydration stress, lipidprotein membranes are the most endangered structures due to the easy peroxidation of the polyunsaturated fatty acids of the membrane phospholipids. Moreover, during freezing and defrosting of plant material, spontaneous mutations and biochemical and structural changes may occur in cells. Therefore, plant material should be analyzed before and after freezing using techniques to verify the integrity of the material such as testing for somaclonal variation of embryogenic callus (Nawrot-Chorabik 2009).

Cryopreservation can be done in different ways, in cryotubes in a Mr Frosty vessel (Nalgene USA) to decrease the temperature slowly by $1{ }^{\circ} \mathrm{C}$ in an automatic Cryo Bath apparatus (CryolLogic) equipped with a freezing system control. In the cryopreservation method developed for Caucasian fir embryogenic callus by Nawrot-Chorabik and Sitko (2014), abscisic acid (ABA) was more effective than dimethyl sulfoxide (DMSO) as a cryoprotectant. Stepwise changes in temperature during freezing and unfreezing of callus tissue provide satisfactory results for living callus tissue, from which physiologically typical embryos can 
develop and undergo further organogenesis (NawrotChorabik and Sitko 2014). Cryopreservation of in vitro cultures is the only existing method to protect plant tissue during long-term storage at low temperatures because it plays a significant role in maintaining profitability of low hydration in embryo tissue or embryonic axis of orthodoxcategory seeds (Berjak and Pammenter 2013). Populus and Salix species (Nawrot-Chorabik 2015b) are examples of plants that produce seeds tolerant to dehydration below $5.0 \%$ humidity.

Although callus tissue cultures, including tree callus tissue induced in vitro by somatic emvbryogenesis has been well studied, many aspects of this field remain uninvestigated and require detailed analyses. Future research should focus on optimizing embryogenesis protocol(s) for a broad range of species and analyses including the study of proteins produced by callus and the genes responsible for particular biochemical and physiological processes. Thus, studies on the selection, culture, physiology and molecular biology of forest trees will advance and be sustained to provide greater benefit in more areas.

Open Access This article is distributed under the terms of the Creative Commons Attribution 4.0 International License (http://crea tivecommons.org/licenses/by/4.0/), which permits unrestricted use, distribution, and reproduction in any medium, provided you give appropriate credit to the original author(s) and the source, provide a link to the Creative Commons license, and indicate if changes were made.

\section{References}

Abul-Soad AA, Mahdi SM (2010) Commercial production of tissue culture date palm (Phoenix dactylifera L.) by inflorescence technique. J Genet Eng Biotechnol 8:39-44

Agrawal V, Sharma K (2006) Phytotoxic effects of Cu, Zn, Cd and Pb on in vitro regeneration and concomitant protein changes in Holarrhena antidysenterica. Biol Plant 50:307-310

Berjak P, Pammenter NW (2013) Implications of the lack of desiccation tolerance in recalcitrant seeds. Front Plant Sci 4:1-9

Bołonkowska O, Pietrosiuk A, Sykłowska-Baranek K (2011) Plant dyes, their biological properties and possibilities of their production in in vitro cultures. Bull Fac Pharm Med Univ Wars $1: 1-27$

Bourgaud F, Gravot A, Milesi S, Gontier E (2001) Production of plant secondary metabolites: a historical perspective. Plant Sci 161:839-851

Chalupa V (1985) Somatic embryogenesis and plantlet regeneration from cultured immature and mature embryos of Picea abies (L.) Karst. Commun Inst For Czech Repub 14:57-63

Corredoira E, Balleste A, Vieitez AM (2003) Proliferation, maturation and germination of Castanea sativa Mill. Somatic embryos originated from leaf explants. Ann Bot 92:129-136

Cusidó RM, Palazón J, Navia-Osorio A, Mallol A, Bonfill M, Morales C, Piñol MT (1999) Production of Taxol and baccatin III by a selected Taxus baccata callus line and its derived cell suspension culture. Plant Sci 146:101-107

Cyr DR, Klimaszewska K (2002) Conifer somatic embryogenesis: II. Applications. Dendrobiology 48:41-49
Das K, Dang R, Ghanshala N, Rajasekharan PE (2008) In vitro establishment and maintenance of callus of Taxus wallichiana Zucc. for the production of secondary metabolites. Nat Prod Radiance 7:150-153

Dörnenburg H, Knorr D (1995) Strategies for the improvement of secondary metabolite production in plant cell cultures. Enz Microb Technol 17:674-684

Ďurkovič J, Mišalová A (2008) Micropropagation of temperate noble hardwoods: an overview. Funct Plant Sci Biotechnol 2:1-9

Giri CC, Shyamkumar B, Anjaneyulu C (2004) Progress in tissue culture, genetic transformation and applications of biotechnology to trees: an overview. Trees 18:115-135

Hakman I, Fowke LC, Von Arnold S, Eriksson T (1985) The development of somatic embryos in tissue cultures initiated from immature embryos of Picea abies (Norway spruce). Plant Sci 38:53-59

Hargreaves C, Menzies M (2007) Organogenesis and cryopreservation of juvenile radiata pine. In: Jain SM, Häggman $\mathrm{H}$ (eds) Protocols for micropropagation of woody trees and fruits, vol 6 . Springer, Berlin, pp 51-66

Hazubska-Przybył T, Chmielarz P, Michalak M, Bojarczuk K (2010) Cryopreservation of embryogenic tissues of Picea omorika (Serbian spruce). Plant Cell Tissue Org Cult 102:35-44

Hazubska-Przybył T, Chmielarz P, Michalak M, Dering M, Bojarczuk K (2012) Vitrification metod of ambryogenic tissues of spruce trees (Picea spp.). Biotechnologia 93:242

Hazubska-Przybył T, Chmielarz P, Michalak M, Dering M, Bojarczuk K (2013) Survival and genetic stability of Picea abies embryogenic cultures after cryopreservation using a pregrowthdehydration method. Plant Cell Tissue Org Cult 113:303-313

Heinze B, Schmidt J (1995) Monitoring genetic fidelity vs somaclonal variation in Norway spruce (Picea abies) somatic embryogenesis by RAPD analysis. Euphytica 85:341-345

Hendry SJ, Boddy L, Lonsdale D (1993) Interactions between callus cultures of European beech, indigenous ascomycetes and derived fungal extracts. New Phytol 123:421-428

Herdt RW (2006) Biotechnology in agriculture. Annu Rev Biochem 31:265-295

Klimaszewska K, Park YS, Overton C, Maceacheron I, Bonga JM (2001) Optimized somatic embryogenesis in Pinus strobus L. In Vitro Cell Dev Biol Plant 37:392-399

Klimaszewska K, Overton C, Stewart D, Rutledge RG (2010) Initiation of somatic embryos and regeneration of plants from primordial shoots of 10-year-old somatic white spruce and expression profiles of 11 genes followed during the tissue culture process. Planta 233:635-647

Komaraiah P, Amrutha RN, Kavi Kishor PB, Rhamakrishna SV (2002) Elicitor enhanced production of plumbagin in suspension cultures of Plumbagino rosea L. Enzyme Microb Technol 31:634-639

Kowalski T, Kehr RD (1992) Endophytic fungal colonization of branch bases in several forest tree species. Sydowia 44:137-168

Kraj W, Dolnicki A, Nawrot-Chorabik K (1999) Sterilisation of the explants from beech (Fagus sylvatica $\mathrm{L}$.) for the in vitro cultures. Biol (Bratislava) Sect Bot 54(7):33

Lelu-Walter MA, Bernier-Cardou M, Klimaszewska K (2008) Clonal plant production from self- and cross-pollinated seed families of Pinus sylvestris (L.) through somatic embryogenesis. Plant Cell Tissue Org Cult 92:31-45

Litz RE, Moon PA, Chavez VM (1995) Somatic embryogenesis from leaf callus derived from mature trees of the cycad Ceratozamia hildae (Gymnospermae). Plant Cell Tissue Org Cult 40:25-31

Malá J, Máchová P, Cvrčková H, Čížková L (2005) Use of micropropagation for gene resources reproduction of noble deciduous species (Malus sylvestris, Pyrus pyraster, Sorbus 
torminalis, S. aucuparia and Prunus avium). Rep For Res 50:219-224 (in Czech)

Malá J, Cvikrová M, Chalupa V (2007) Micropropagation of mature trees of Ulmus glabra, Ulmus minor and Ulmus laevis. In: Jain SM, Häggman $\mathrm{H}$ (eds) Protocols for micropropagation of woody trees and fruits, vol 22. Springer, Berlin, pp 237-248

McCown BH (2003) Biotechnology in horticulture: 100 years of application. Hort Sci 38:1026-1030

Mihaljevic S, Jelaska S (2005) Omorica spruce (Picea omorica). In: Jain SM, Gupta P (eds) Protocol for somatic embryogenesis in woody plants. Forestry sciences, vol 77 . Springer, Berlin, pp 35-46

Misson JP, Druart P, Panis B, Watillon B (2006) Contribution to the study of the maintenance of somatic embryos of Abies nardmaniana Lk: culture media and cryopreservation method. Prop Ornam Plants 6:17-23

Mulabagal V, Tsay HS (2004) Plant cell cultures-an alternative and efficient source for the production of biologically important secondary metabolites. Int J Appl Sci Eng 2:29-48

Murashige T, Skoog F (1962) A revised medium for rapid growth and bioassays with tobacco tissue cultures. Physiol Plant 15:473-494

Naujoks G (2007) Micropropagation of Salix caprea L. In: Jain SM, Häggman $\mathrm{H}$ (eds) Protocols for micropropagation of woody trees and fruits, vol 20. Springer, Berlin, pp 213-220

Nawrot-Chorabik K (2007) Induction and development of Grand Fir (Abies grandis Lindl.) callus in tissue cultures. Electr J Polish Agric Univ 10:1-11

Nawrot-Chorabik K (2008) Embryogenic callus induction and differentiation in silver fir (Abies alba Mill.) tissue culture. Dendrobiology 59:31-40

Nawrot-Chorabik K (2009) Somaclonal variation in embryogenic cultures of silver fir (Abies alba Mill.). Plant Biosyst 143:377-385

Nawrot-Chorabik K (2012) Embryogenesis. In: Ken-Ichi S (ed) Somatic embryogenesis in forest plants, vol 20. InTech open science Publisher, Rijeka, pp 423-446

Nawrot-Chorabik K (2013) Possible use dual cultures in the forestry practice. Sylwan 157:54-62

Nawrot-Chorabik K (2014) Interactions between embryogenic callus of Abies alba and Heterobasidion spp. in dual cultures. Biol Plant 58:363-369

Nawrot-Chorabik K (2015a) The effect of explant origin, media and growth regulators on the initiation and proliferation of embryogenic callus of Pinus sylvestris in somatic embryogenesis. Phyton-Ann Rei Bot 55:279-295

Nawrot-Chorabik K (2015b) Zastosowanie tkanki kalusa w biotechnologii drzew leśnych: badania in vitro. Kosmos 64: 305-317 (The use callus tissue in forest tree biotechnology: studies in vitro. Cosmos 64:305-317

Nawrot-Chorabik K (2016) Plantlet regeneration through somatic embryogenesis in Nordmann's fir (Abies nordmanniana). J For Res 27:1219-1228

Nawrot-Chorabik K (2017) Response of the callus cells of fir (Abies nordmanniana) to in vitro heavy metal stress. Folia For Pol Ser A For 59:25-33

Nawrot-Chorabik K, Jankowiak R (1999) Preliminary studies on disinfection of explants of grand fir (Abies grandis Lindl.) used in in vitro cultures for micropropagation of fir. Sci Papers Acad Agric 28:39-50

Nawrot-Chorabik K, Sitko K (2014) The effect of abscicsic acid and dimethyl sulfoxide and different temperatures on the cryopreservation process of Abies nordmanniana (Steven) Spach embryogenic callus. Phyton-Ann Rei Bot 55:279-295
Nawrot-Chorabik K, Jankowiak R, Grad B (2011) Growth of two blue-stain fungi associated with Tetropium beetles in the presence of callus cultures of Picea abies. Dendrobiology 66:41-47

Nawrot-Chorabik K, Grad B, Kowalski T (2016) Interactions between callus cultures of Pinus sylvestris and pine fungi with different trophic properties. For Pathol 46:179-186

Nhut DT, Hien NTT, Don NT, Khiem DV (2007) In vitro shoot development of Taxus wallichiana Zucc., a valuable medicinal plant. In: Jain SM, Häggman H (eds) Protocols for micropropagation of woody trees and fruits, vol 10. Springer, Berlin, pp 107-116

Palo RT (1984) Distribution of birch (Betula spp.), willow (Salix spp.), and poplar (Populus spp.) secondary metabolites and their potential role as chemical defense against herbivores. J Chem Ecol 10:499-520

Park YS (2001) Implementation of somatic embryogenesis in clonal forestry: technical requirements and deployment strategies. In: International Conference on: Wood, Breeding, Biotechnology and Industrial expectations, Abstract, Bordeaux, pp 106

Rangaswamy NS (1986) Somatic embryogenesis in angiosperm cell tissue and organ cultures. Proc Plant Sci 96:247-271

Rao PS (1965) In vitro induction of embryonic proliferation in Santalum album L. Phytomorphology 15:175-179

Rodríguez R, Valledor L, Sánchez P, Fraga MF, Berdasco M, Hasbún R, Rodríguez JL, Pacheco JC, García I, Uribe MM, Ríos D, Sánchez M, Materán ME, Walter C, Cañal MJ (2007) Propagation of selected Pinus genotypes regardless of age. In: Jain SM, Häggman $\mathrm{H}$ (eds) Protocols for micropropagation of woody trees and fruits, vol 13. Springer, Berlin, pp 137-146

Salaj T, Salaj J (2003) Somatic embryo formation on mature Abies alba $\times$ Abies cephalonica zygotic embryo explants. Biol Plant 47:7-11

Schulz B, Boyle Ch, Draeger S, Römmert AK, Krohn K (2002) Endophytic fungi: a source of novel biologically active secondary metabolites. Mycol Res 106:996-1004

Seki M, Nakajima M, Furusaki S (1995) Continuous production of taxol by cell culture of Taxus cuspidata. J Chem Eng Jpn 28:488-490

Sparg SG, Light ME, Van Staden J (2004) Biological activities and distribution of plant saponins. J Ethnopharm 94:219-243

Steward FC (1958) Growth and development of cultivated cells. III. Interpretations of the growth from free cell of carrot. Am J Bot 45:709-713

Szczygieł K (2005) Somatic embryogenesis-alternative way of obtaining selected planting stock of coniferous tree species. For Res Papers 3:71-92

Szczygieł K, Wojda T (2008) Micropropagation of wild cherry (Prunus avium L.) and its plantation cultivation in Italy. For Res Papers 69:72-75

Toribo M, Celestino C, Molinas M (2005) Cork oak, Quercus suber L. In: Jain SM, Gupta P (eds) Protocol for somatic embryogenesis in woody plants. Forestry sciences, vol 77. Springer, Berlin, pp 445-458

Walters C, Find JI, Grace LJ (2005) Somatic embryogenesis and genetic transformation in Pinus radiata. In: Jain SM, Gupta P (eds) Protocol for somatic embryogenesis in woody plants. Forestry Sciences, vol 2. Springer, pp 11-24

Wang Ch, Wu J, Mei X (2001) Enhancement of Taxol production and execration in Taxus chinensis cell culture by fungal elicitation and medium renewal. Appl Microbiol Biotechnol 55:404-410 